Young larvæ from Calliphora vomitoria gave a weak signal, but the signal was larger when older larvæ were examined and larger still when pupæ and adults of equivalent weight were placed in the resonance cavity. We initially thought that this might have been due to free radicals present in rapidly growing tissues but the fact that the adults gave the largest signal indicated that another factor might be important. This was confirmed when we found that adult Calliphora still gave a strong signal after being dead for several hours at room tempera-

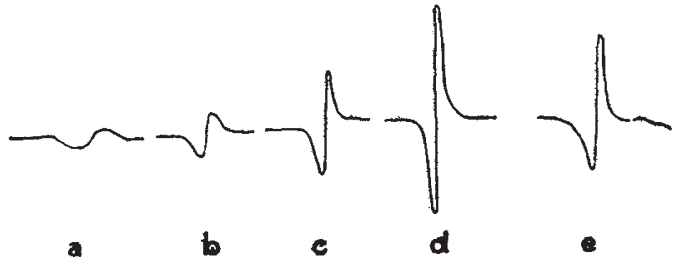

Fig. 2. Signals obtained from Calliphora vomitoria. a, from young maggots ; $b$, from pupæ ; $c$, from adult ; $d$, from adults melanin extracted from adult Calliphora

ture. The progression larvæ-pupæ-adult shows an increase in pigmentation, and it is possible that the melanins responsible for the pigmentation are responsible for the signals. This was partially confirmed by the fact that the melanins when extracted from adult flies gave a good signal as shown in Fig. $2 e$.

These two sets of results, though of a preliminary nature, indicate the value of electron spin resonance studies as a tool in biological research. Full details of this work will be published at a later date.

M. EDWARDS

G. A. Kerkut

K. A. Munday

Department of Biochemistry and Physiology,

D. J. INGRAM

M. C. Saxena

K. LeACH

Department of Electronics,

University of Southampton.

1 Commoner, B., Townsend, J., and Pake, G., Nature, 174, 689 (1954). Truby, F., and Goldzieher, J., Nature, 182, 1371 (1958).

\section{ANIMAL PHYSIOLOGY}

\section{Effects of Elevated Plasma Sodium \\ Concentration on Sodium and Potassium in the Erythrocyte of the Lizard Trachysaurus rugosus (Gray)}

THE lizard Trachysaurus rugosus has been shown to tolerate very high plasma sodium concentrations, for example, $240 \mathrm{~m}$. equiv./l., both in its natural habitat during summer and in the laboratory after the injection of sodium chloride solution ${ }^{1}$. The injected sodium chlorate reached osmotic equilibrium with the total body water but electrolyte changes inside the cells were not determined. The nucleated erythrocytes of Trachysaurus offered a useful starting point for intracellular studies in vivo. It has been shown in vitro that the sodium concentration in the nucleated erythrocytes of the turtle is actively maintained by respiration ${ }^{2}$

Intraperitoneal injections (1 gm./100 gm./bodyweight) or a 6 per cent $(\mathrm{w} / \mathrm{v})$ sodium chloride solution were given to the animals on each of six successive days. Blood samples, $2 \mathrm{ml}$., were collected by heart puncture into heparinized syringes. Sodium and potassium concentrations in the cells were calculated from their concentration in whole blood and in plasma and the hæmatocrit values ${ }^{3,4}$. Electrolyte concentrations were determined with an $E E L$-flame photometer. Cell water was calculated from water content of the whole blood and plasma and hæmatocrit value; dry weights being determined after $24 \mathrm{hr}$, at $105^{\circ} \mathrm{C}$. The animals were kept at $21^{\circ} \mathrm{C}$. and given nothing to eat or drink during the experiment.

After the second injection of sodium chloride solution no water had been lost from the erythrocytes, but both sodium and potassium concentrations inside the cells had risen, sodium more than potassium. The small decrease in hæmatocrit would be consistent with the removal of two ml. of blood in the initial sample. After the sixth injection of sodium chloride solution, the hæmatocrit had decreased much more than would be expected from the blood samples previously taken. The values for cell water in Table 1 are expressed as $\mathrm{w} / \mathrm{v}$. The change in $\mathrm{w} / \mathrm{v}$ between the 2nd and 6th day corresponds to a 23 per cent decrease in cell volume. This would explain a substantial part of the change in hæmatocrit and would correspond to a loss of 30 per cent of the original content of water. Despite such a degree of cellular dehydration, the sodium concentration in the cell water was no higher than on the second day and sodium content of the cells must therefore have been diminished. This suggests an active extrusion of sodium. On the other hand the intracellular potassium concentration rose, and this increase could be satisfactorily explained by the observed loss, presumably osmotic, of cell water with little or no change in the cellular content of potassium. Detailed results are given in Table 1.

Table 1. EFFects of SODIUM ChLORIDE INJECTMNS ON SODIUM AND

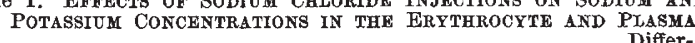

\begin{tabular}{|c|c|c|c|c|c|c|c|}
\hline & \multirow[t]{2}{*}{$\underset{\text { tocrit }}{\text { Homa- }}$} & \multirow{2}{*}{$\begin{array}{c}\begin{array}{c}\text { Cell } \\
\text { water }\end{array} \\
w / v\end{array}$} & \multicolumn{2}{|c|}{$\begin{array}{l}\text { Plasma } \\
\text { m. equiv. } \\
\text { l./water }\end{array}$} & \multicolumn{2}{|c|}{$\begin{array}{l}\text { Cell } \\
\text { m. equiv./ } \\
\text { l. water }\end{array}$} & \multirow{2}{*}{$\begin{array}{c}\text { Differ- } \\
\text { ence } \\
\text { between } \\
\text { Plasma } \\
\text { and } \\
\text { Cell } \\
\mathrm{Na}+\mathrm{K}\end{array}$} \\
\hline & & & $\mathrm{Na}$ & $\mathbf{K}$ & $\mathrm{Na}$ & $\mathbf{K}$ & \\
\hline Initial & $\begin{array}{r}26.21 \\
+1.47\end{array}$ & $\begin{array}{r}75.74 \\
\pm 1.11\end{array}$ & $\begin{array}{c}167 \cdot 7 \\
\pm 2 \cdot 72\end{array}$ & $\begin{array}{r}4 \cdot 77 \\
\pm 0 \cdot 17\end{array}$ & $\begin{array}{r}49 \cdot 8 \\
\pm 5 \cdot 0\end{array}$ & $\begin{array}{l}124 \cdot 7 \\
\pm 2 \cdot 92\end{array}$ & $\begin{aligned} & 2 \cdot 1 \\
\pm & 7 \cdot 43\end{aligned}$ \\
\hline $\begin{array}{l}24 \mathrm{hr} \text {. after } \\
\text { 2nd inject. }\end{array}$ & $\begin{array}{c}24 \cdot 3 \\
\pm 1 \cdot 48\end{array}$ & $\begin{array}{r}75 \cdot 69 \\
\pm 1.12\end{array}$ & $\begin{array}{l}192 \cdot 1 \\
\pm 3 \cdot 15\end{array}$ & $\begin{array}{r}4 \cdot 25 \\
\pm 0 \cdot 25\end{array}$ & $\begin{array}{c}86 \cdot 6 \\
\pm 9 \cdot 37\end{array}$ & $\begin{array}{l}142 \cdot 8 \\
\pm 3 \cdot 42\end{array}$ & $\begin{array}{ll} & 34.8 \\
\pm & 10.92\end{array}$ \\
\hline $\begin{array}{l}24 \mathrm{hr} \text {. after } \\
6 \mathrm{th} \text { inject. }\end{array}$ & $\begin{array}{c}15.1 \\
\pm 1.04\end{array}$ & $\begin{array}{r}68.56 \\
\pm 2.25\end{array}$ & $\begin{array}{l}250 \cdot 3 \\
\pm 2 \cdot 24\end{array}$ & $\begin{array}{r}3 \cdot 60 \\
\pm 0.22\end{array}$ & $\begin{array}{c}85 \cdot 0 \\
\pm 6.41\end{array}$ & $\begin{array}{l}196 \cdot 4 \\
\pm 3 \cdot 30\end{array}$ & $\begin{aligned} & 27.6 \\
\pm & 10.06\end{aligned}$ \\
\hline
\end{tabular}

Initially the sum of the concentration of the cations sodium and potassium was the same in the cell water as in the plasma water. After both the second and sixth injection of sodium chloride solution the intracellular concentrations exceeded those in the plasma. Assuming osmotic equality of the two fluids this indicates an increased dissociation of polyvalent organic anions in the cells. Excess chloride in the plasma might be compensated by decrease in bicarbonate. In rabbits, it has been shown that plasma bicarbonate concentrations diminish after injection of hypertonic sodium chloride solution ${ }^{5}$.

Physiology Department,

$$
\text { P. J. BentLey }
$$

University of Western Australia, Perth. June 5 .

\footnotetext{
1 Bentley, P. J., J. Physiol., 145, 37 (1959).

1 Maizels, M., J. Physiol, 132,414 (1956).

Evans, J. V., J. Physiol., 136, 4 (1957)

Barker, J. M., Nature, 181, 492 (1958). (1940).
} 